\title{
EVALUATION OF FACTOR OF HOSPITALITY IN SARAJEVO TOURISM DESTINATION
}

\author{
Lejla Žunić ${ }^{1}$
}

\begin{abstract}
Hospitality, as a cultural receptional factor, has a great importance for a tourism planning and tourism \& geographical destination development. Research problem considers an analysis and evaluation of hospitality in Sarajevo tourism destination. The aim of this article is to research the basic parameters/ indicators of hospitality in order to understand their value. Parameters of hospitality are: qualifications, affability and English language skills. The basic methodology will include collecting data for statistical analysis and survey research that will be used to assess opinions of tourists, tourism managers and tourism employees.
\end{abstract}

Key words: Sarajevo tourism destination, hospitality, tourism, qualifications, affability, English language skills, tourism planning, tourism \& geographical development.

\section{Introduction}

The factor of hospitality is a cultural receptional tourism factor. Hospitality can be defined as a "face to face" interaction between consumer and a seller (Dobre, R., Rusković, P., Čivljak, M., 2004, p. 32). Brotherton (1999) defines hospitality as making the guest "feel at home" (Smet, T., 2003, pp. 5, 8). Hospitality has a multiple influence at tourist arrivals, but it's even more important at propaganda effects and increasing consumers. Hospitality include qualifications of tourism staff and affability (Jovičić, Ž., 1986). Qualifications should consider the right diploma of workplace as well as an education degree. Affability of destination means more then just a kindness of tourism staff, it's about kindness of local people or sellers as well, etc. English language is the global language that connect people and help them to understand each other. Same time, the understanding of tourist needs is the priority thing for a successful tourism development. Therefore, it is very important to research and to do evaluation of factor of hospitality in Sarajevo, that has a positive tourism growth during the last decade. This study will explore the recent characteristics of hospitality, as a key factor of welcoming destination for tourists.

\section{Background}

Sarajevo tourism destination has a positive tourism growth. There's a significant increase in the number of tourists $(1999: 55177,2009: 156081,2012: 256628)$ and the overnight stays (1999: 138657, 2009: 290308, 2012: 504929). Foreign tourist participation is more then $80 \%$ in total arrivals. The structure of arrivals is very different, the biggest share takes tourists from Croatia 17,4\%, Turkey 13,9\%, Slovenia 8,1\%, Serbia 4,9\%, Germany 4,4\%, Italy, Kuwait, South Korea and USA. On the other hand, tourists from Croatia 14,9\%, Turkey $12,8 \%$ and Kuwait 9,7\%, takes the biggest share in the overnight stays. (Tourism Association of Sarajevo Canton, Sarajevo)

\footnotetext{
${ }^{1}$ Senior teaching assistant \& doctorant, Department of Geography, Faculty of Sciences, University of Sarajevo, Bosnia and Herzegovina, e-mail: pmflejlazunic@yahoo.com.
} 


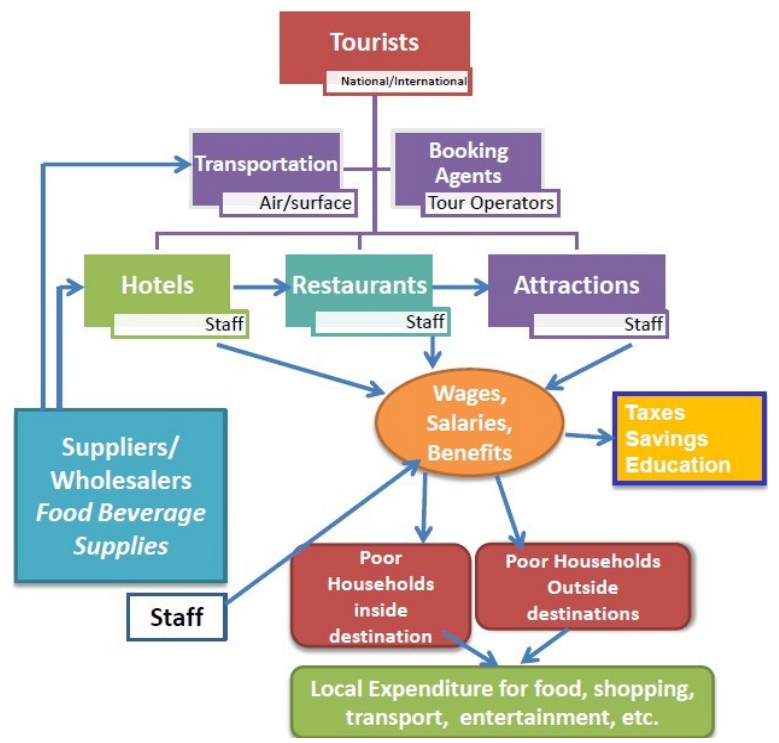

Fig. 1. Integral Concept of Hospitality \& Tourism - interactivity of services

(Khan, M., 2012)

According to the integral concept of a hospitality \& tourism, all services are interactively connected in a very compound system. This system consist different needs of tourists (informations, lifting, accomodation, food \& drink), but also an affability/ kindness of a tourism staff, etc. Thus, hospitality \& tourism industry includes:

- Hotels, restaurants, air flights, surface transportation, attractions, museums, schools, colledge, accomodation.

- Impresion.

- $\quad$ Services are intangible, heterogeneous, consumable.

- Contact includes smile, cultural diversity and calmness. (Khan, M., 2012)

According to the official statistics for 2011 year, hospitality \& tourism takes $4,5 \%$ in a total employment of Sarajevo. (Institute for Statistics of Federation of Bosnia \& Herzegovina) 


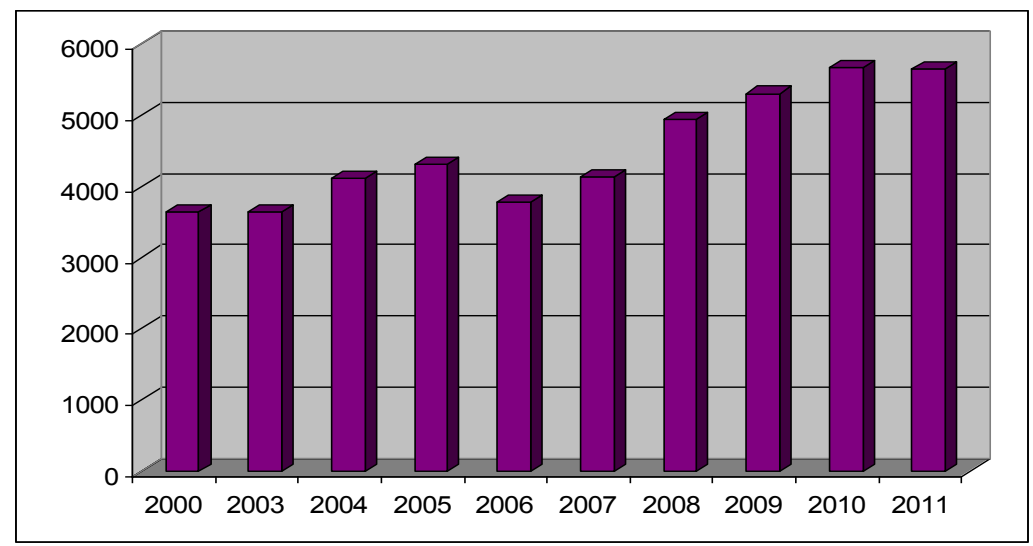

Fig. 2. Growth of employees in Sarajevo hospitality \& tourism 2000-2011 year

(Institute for Statistics of Federation of Bosnia and Herzegovina)

The graph above (fig.2) shows that Sarajevo tourism destination, generally, has a positive growth of employees in a hospitality \& tourism sector during the decade period (2000: 3637; 2011: 5649). This indicates profitable and sustainable development of hospitality services. The results of terrain observations show a positive growth of accomodations and restaurants (caffe, restaurants, etc.) on the southwest of Sarajevo (Ilidža), near to health \& recreative motives (thermal baths, Spring of river Bosnia), as well as besides the main traffic roads and in a downtown (Titova, Ferhadija st.), while their biggest concentration is in the oldtown of a destination (Bascharshia), which is the top tourist attraction.

Tab. 1. Traffic growth in a hospitality \& tourism of Sarajevo destination 2009-2013

\begin{tabular}{|l|r|r|r|r|r|}
\hline & $\mathbf{2 0 0 9}$ & $\mathbf{2 0 1 0}$ & $\mathbf{2 0 1 1}$ & $\mathbf{2 0 1 2}$ & $\mathbf{2 0 1 3}$ \\
\hline Hotels, etc. & 47.928 & 51.912 & 48.789 & 54.778 & 60.567 \\
\hline Resorts, camps & 1.021 & 1.181 & 788 & 682 & 626 \\
\hline Restaurants, etc. & 7.033 & 6.781 & 5.755 & 11.937 & 15.701 \\
\hline Catering & 1.353 & 1.405 & 1.516 & 1.396 & 1.204 \\
\hline Food \& drink service & 5.423 & 4.117 & 3.608 & 3.192 & 2.995 \\
\hline Total: & $\mathbf{6 2 . 7 5 8}$ & $\mathbf{6 5 . 3 9 6}$ & $\mathbf{6 0 . 4 5 6}$ & $\mathbf{7 1 . 9 8 5}$ & $\mathbf{8 1 . 0 9 3}$ \\
\hline
\end{tabular}

(Statistical Yearbook of Canton Sarajevo for 2013 year, 2014)

According to the table, Sarajevo tourism destination has a positive traffic growth in its hospitality \& tourism over the 2009-2013 year. Hotels has the biggest traffic participation, as the overnight stays takes about $53 \%$ in a total services. 


\section{Materials and Methods}

Research methodology includes the collecting data for statistical analysis of hospitality parameters and the survey that will be used to assess opinions of tourists, tourism managers and tourism employees. Statistical analysis explore the growth of hospitality and the things that has changed considerably over the last decade. Evaluation of the survey results will be measured at different scales (Likert, nominal, ordinal). The survey was taken in Sarajevo tourism destination, mostly in the hotels and tourism agencies, during 2013-2014 year. There were 186 respondents to the survey: 20 tourism managers or assistant managers, 59 employees- tourism staff, 107 tourists who visited Sarajevo in 2013-2014 year. They survey for tourism managers and assistant managers was taken at the next hotels: Bristol, Europa, Art, Terme, Hercegovina, Crystal, Hollywood, and tourism agencies: Relax Tours, Gaudi Lufthansa, Zoi '84, Bosnia Travel, Reyyan, Akdeniz, Euroservices in 2013 year. The survey for tourism employees was taken at the next hotels: Bristol, Europa, Art, Dardanija, Holiday, Hollywood, and tourism agencies: Relax Tours, Kompas, Avio Ekspress, Zoi '84, Sol Azur, Gaudi Lufthansa, Bosnia Travel, Reyyan, Euroservis in 2013 year. The survey for tourists, the visitors of Sarajevo destination, was taken at different locations (mostly in the oldtown of Sarajevo) in 2013-2014 year, the tourists stayed in next accommodations: hotels Europa, Hollywood, Bristol, Astra Garni, Imzit, Dardanija, Lula, Old Town, Emona, Mostardayiz, ETN, Radon Plaza, City Boutique, Terme, Michele, hostels Doctor's House, For Me, Guest House, Max, Kovači, Franz Ferdinand, Vagabond, private accomodation, apartments. The survey results will provide the evaluation of factor of hospitality that will be based on a single value of defined parameters (qualifications, affability and English).

\section{Results and Discussions}

Services that tourists consume (accomodation, food, fun, travels) depends on the competences and organisation skills of touroperators in a tourism destination. Tourism employees in a hotels and tourism agencies, etc., are daily dealing with tourists. Besides, tourists also make contact with local inhabitants of a tourism destination. Consequently, the level of hospitality services can be measured by three important indicators/ parameters:

1) Qualifications (a profession and an education degree),

2) Affability (kindness and a cultural behavior toward tourist clients),

3) English language skills.

4)

\subsection{Qualifications of tourism staff}

Qualifications of a tourism staff can be measured by analysis and evaluation of defined indicators such as: a profession and an education degree. Education degree can be next levels: university degree (undergraduate or postgraduate), college degree, highschool and secondary education, primary (elementary) education, high skilled, skilled, medium and low skilled workers. 
Tab. 2. Growth of a number of employees in Sarajevo hospitality \& tourism according to the education degree 2003-2011 year

\begin{tabular}{|l|r|r|r|}
\hline Qualifications & $\mathbf{2 0 0 3}$ & $\mathbf{2 0 0 7}$ & $\mathbf{2 0 1 1}$ \\
\hline University degree & 55 & 70 & 140 \\
\hline College Degree & 38 & 47 & 500 \\
\hline Highschool Education & 432 & 500 & 806 \\
\hline Primary Education & 121 & 80 & 236 \\
\hline High Skilled Worker & 59 & 109 & 103 \\
\hline Skilled Worker & 295 & 276 & 429 \\
\hline Medium Skilled Worker & 38 & 25 & 3 \\
\hline Low Skilled Worker & 56 & 65 & 183 \\
\hline
\end{tabular}

(Institute for Statistics of Federation of Bosnia and Herzegovina)

The table above shows the growth of a number of employees in a hospitality \& tourism of Sarajevo Tourism Destination. There can be defined three different development trends:

a) progressive growth - increasing number of employees with university and college degree, then highschool education, as well as a low skilled workers,

b) regressive growth - decreasing number of employees that have a medium skilled qualifications,

c) uneven growth- oscillating number of employees with primary education, as well as high skilled and skilled workers.

Highschool \& secondary educational take the largest share of Sarajevo hospitality structure (2003: 39,5\%; 2011: 41\%), then skilled workers (2003: 27\%; 2011: 22\%), primary education (2003: 11,7\%, 2011: 12\%) and university degree (2003: 5\%, 2011: 9\%). It's important to emphasize the progressive growth of employees with university degree because it can be a good indicator of improving tourism in Sarajevo destination. Better qaulified provides the better hospitality service as a key of tourism success. 


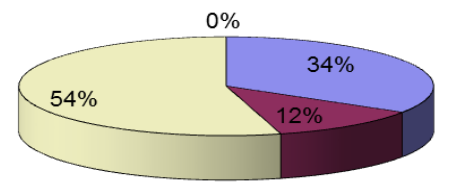

口a) University degree

ab) College degree

口c) Highschool education

口d) Primary education

Fig. 3. An educational structure of employees at some hotels and tourism agencies in Sarajevo Tourism Destination 2013 year

(The Survey of Tourism Employees Results, 2013)

The graph above shows that the highschool education take the largest share of an educational structure of employees at some hotels and tourism agencies (54\%). This is because most of jobs at hotels and tourism agencies can be done well even without university qualifications. Same time, some highschools have a hospitaliy \& tourism programmes, so they can produce a good qualified tourism workers.

Tab. 3. Evaluation of an educational structure of employees at some hotels and tourism agencies in Sarajevo Tourism Destination in 2013 year on the ordinal scale: 1- low, 2- medium, 3- higher, 4- high value

\begin{tabular}{|l|c|c|}
\hline VALUE & MARK & RESPONDENT \\
\hline Low & 1 & 0 \\
\hline Medium & 2 & 32 \\
\hline Higher & 3 & 7 \\
\hline High & 4 & 20 \\
\hline Average: & 2,8 & 59 \\
\hline
\end{tabular}

(The Survey of Tourism Employees Results, 2013)

The table above shows the average mark of an educational structure of employees at some hotels and tourism agencies in Sarajevo tourism destination $(2,8)$. Evaluation of this parametre from the ordinal scale (1-4) reflects the higher value of tourism staff education. 


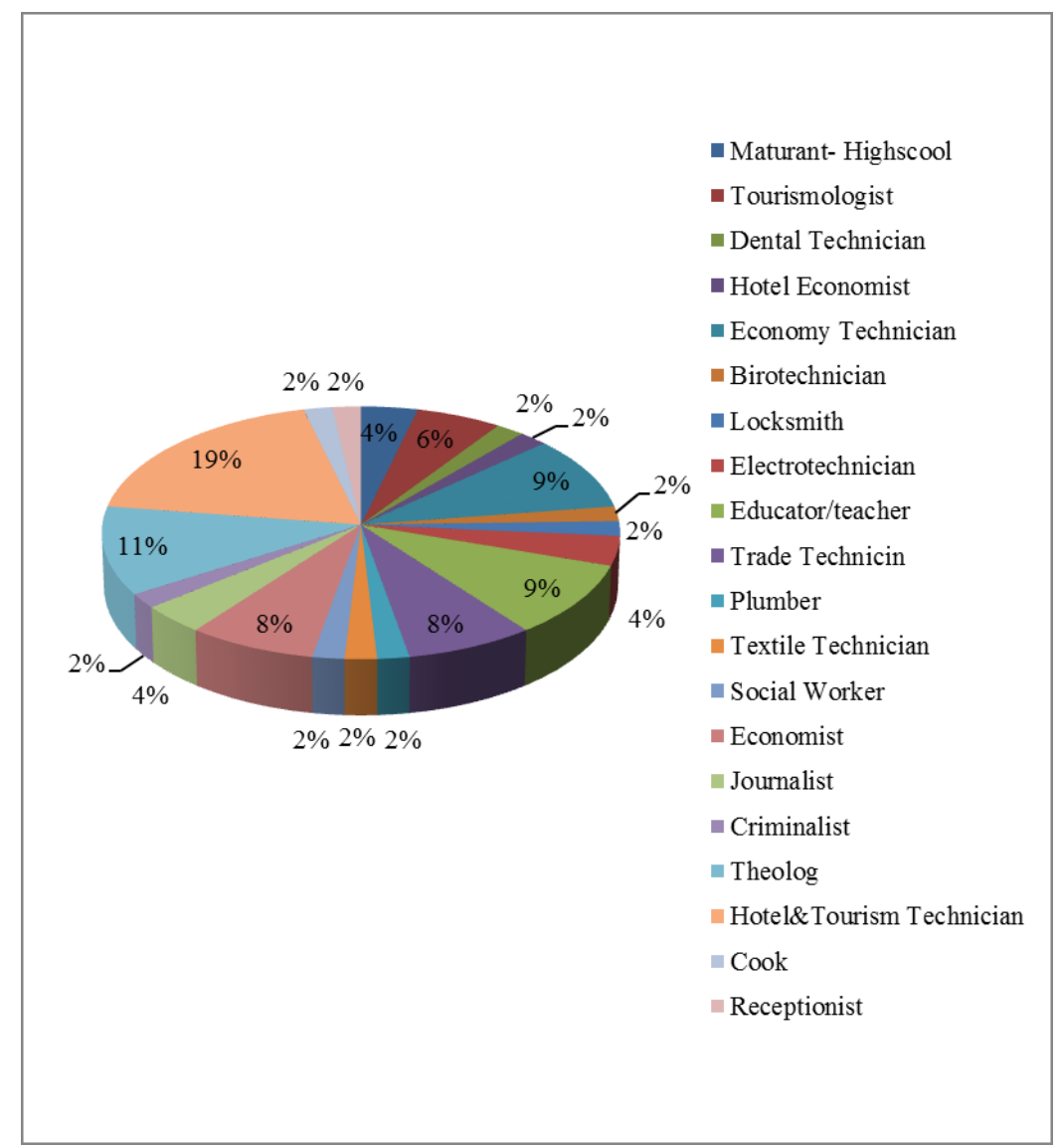

\section{Fig.4.Professional diversity of employees at some hotels and tourism agencies in Sarajevo tourism destination in 2013 year}

(The Survey of Tourism Employees Results, 2013)

The graph above shows the huge diversity of an employees professions at some hotels and tourism agencies in Sarajevo tourism destination. Hotel \& tourism technicians 14\%, theologists $10 \%$ and economy technicians $8 \%$ take the largest share of a professional structure of employees. Economist, trade technician and educator/teacher participate with $7 \%$, while tourismologist $5 \%$. There's an equal share of a tourism technician, journalist, maturant- highschools 3\%, etc. The higher theologist participation is because of successful implementing the project "Tourism in an islamic way (Halal Tourism in Bosnia \& Herzegovina)" under two tourism agencies: "Bosnia Travel" and "Reyyan". This project provided the increase in the number of tourists, visitors of Sarajevo tourism destination, especially muslim tourists from arabic countries (Saudi Arabia, Qatar, Kuwait, United Arabic Emirates, Egypt, etc.). The problem is that the professional structure at the hotels and tourism agencies is not really an adequate, as there should be more workers with hospitality \& tourism qualifications. That's why it's advicable to make the revision of professional qualiffications at hotels and tourism agencies and to do an open competition. To improve hospitality and tourism of Sarajevo destination, there should be done a rational exploitation of houman resourses hospitality and tourism profiles. Hospitality and tourism diploma can be achieved in some secondary schools in Sarajevo (for example, the Secondary Hospitality \& Tourism Vocational School) or faculties of hospitality \& tourism 
(Economy Faculty - Department of Tourism Management, Faculty of Natural Sciences and Mathematics- Department of Geography, Study Course of Tourism \& Environmental Protection, etc.). This schools and faculties producing very important professions, such as: tourist guide, cook, waiter, hotel recepcionist, tourism and marketing manager, geographer- tourismologist, etc. Tourism and hospitality industry need this type of professional qualifications! The possible reasons for somehow inadequate professional structure (occupation) at some hotels and tourism agencies in Sarajevo, could be actualy found at inadequate employment system sometimes:

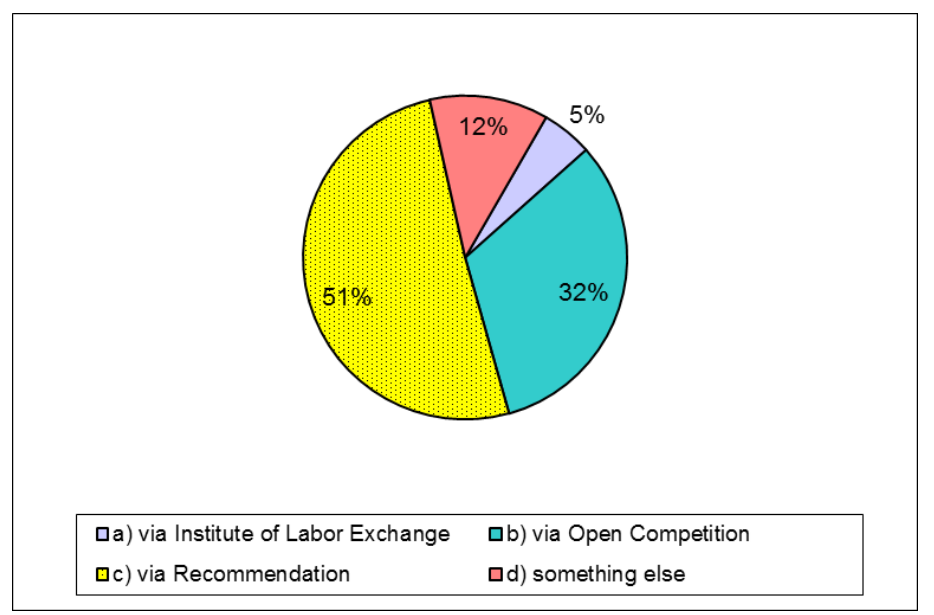

Fig. 5. Employment system at hospitality \& tourism of Sarajevo destination

(The Survey of Tourism Employees, 2013)

According to the graph, there's evident that more then a half of employees in a hospitality $\&$ tourism of Sarajevo got the job thanks to the recommendations 51\%. Recommendation doesn't necessarily means the right qualifications for some job, but it's about a nepotism. "Nepotism is a favoritism directed exclusively or mainly toward friends or relatives, regardless of merit. Today many employers are lending a hand to struggling family members or friends by offering them employment opportunities.' (Wilson, B., 2011) The main motive is that "the job can be learned and trained with the working practice apart from a right education.' Such nepotism shouldn't be a daily practice because knowledge and competences usually comes with an adequate qualifications (education \& experience). However, there's a pleasant fact that more then $1 / 3$ of employees basically have the right qualifications for their job that they were given via Institute of Labor Exchange or at the Open Competition 37\%. 


\subsection{Affability (kindness and cultural behave towards a tourist clients)}

Affability can be defined as a cultural behavior, specific behavior toward tourist clients (guest care) and an educational level. "Hospitality is a completed attitude toward a guest. Different professional profiles must learn a specific tourism education. Therefore, workers of hospitality, transport, trading and other services linked to a tourism, they must to achieve a special tourism education which is very important element of their cultural behavior." (Jovičić, Ž., 1986, p. 104) Guest care can be defined as a high service quality and a professionalism toward a guest. Service quality must accomplish the guest needs and expectations. (Tomašević, A., 2009, p. 3) Tourists have many different needs (accomodation, food \& drink, attractions, transport, fun, recreation, safety, sleep, etc.), but affable treatments is their basic expectation. Kindness, hosting and welcoming is expected from a tourism staff, sellers, bankers, drivers, locals. Cultural level and affability are indeed very important elements of any tourism destination. Services harmony, well organisation, English language skills, affability and guest care, they can indicate the hospitality level of a tourism destination. "Guest care includes:

- Knowing the guest culture \& tradition

- Understanding the personality of a guest

- Identification of guest needs and expectations

- Good knowledge about available services of hotel and tourism product of destination as well

- Communication skills, English language skills

- Responsibility

- Ability to identify \& solve the problems

- Optimism and welcoming for a culture differences

- Candour and a pleasant mood

- A smile. (Tomašević, A., 2009, p. 3)

We could say that the cultural behavior toward a tourist clients is linked with few important factors: a profession (occupation), educational degree, general cultural behavior, character and type of a personality, a psyhological, physical and health condition, communication skills, empathy, understanding the guest needs, a hospitality \& tourism qualifications and orientation, attitude, support and manager treatment and monitoring.

Cultural behavior is a constitutive element of interaction between hosts and tourists. "Tourists are to be served, whereas hosts are the servers; tourists are at leisure, whereas hosts are at work; tourists are motivated by leisure, whereas hosts are motivated by financial gains. As a result, they develop different attitudes and behavior toward each other. Tourists and hosts have also different access to wealth and information, commitment and responsibilities, and socio-economic position and cultural identity. Tourist-host interaction takes place in the (1) spatial (e.g., physical space shared by the tourist and host or physical distance, social status of interactants, rules of behavior they have to conform to), (2) temporal (e.g., length of time tourists stay in the destination, the time of the contact itself, different roles played by interactants), and whether (3) tourists buy goods communicative (e.g., the ability to speak each other's language and understand non-verbal behavior), and (4) cultural (e.g., different cultural values, perceptions, attitudes, willingness of both to share their values and experiences) contexts." (Reisinger, Y., 2009, 
p. 205) In order to make a cultural behavior toward a tourists ethically acceptable, and to across the communication difficulties influenced by cultural differences of tourist and a host of a tourism destination, there was implemented universal code of tourism. The World Tourism Organisation introduced universal code of ethical behavior in a tourism and a tourism destinations called "Global Code of Ethics for Tourism". (United Nations The World Tourism Organisation, UNWTO, GCET 1999)

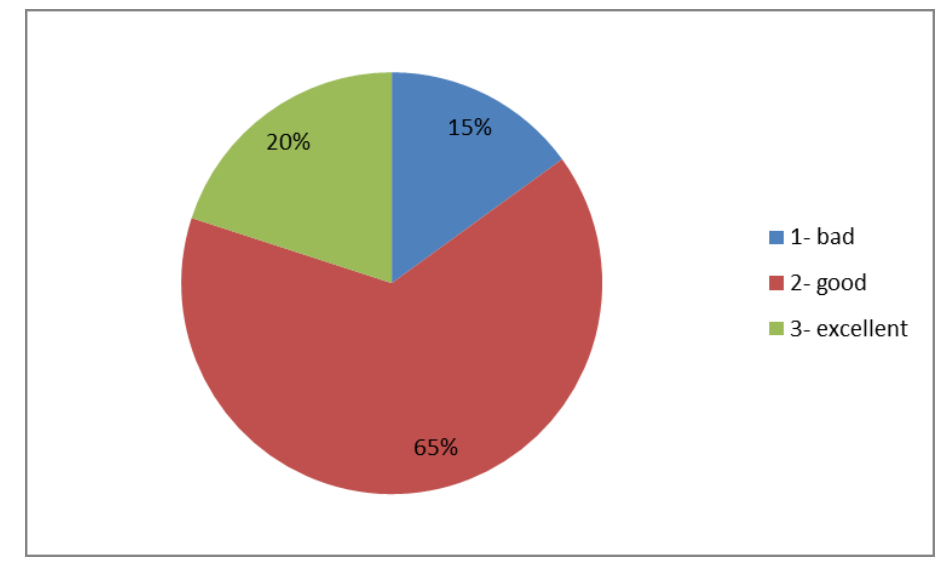

Fig. 6. Evaluation of a tourism staff affability at some hotels and tourism agencies in Sarajevo tourism destination on the Likert scale:

1- bad, 2- good, 3- excellent, according to opinion of a tourism managers or assistant managers

(The Survey of Tourism Managers Results, 2013)

The survey of a tourism managers or assistant managers results shows that the tourism staff affability in Sarajevo destination is mostly good 65\%. Knowing that the tourism staff is a mirror of a tourism destination, it's a welcoming expression and a hosting of tourists, then the managers should affect it more to rise it on the highest level. 


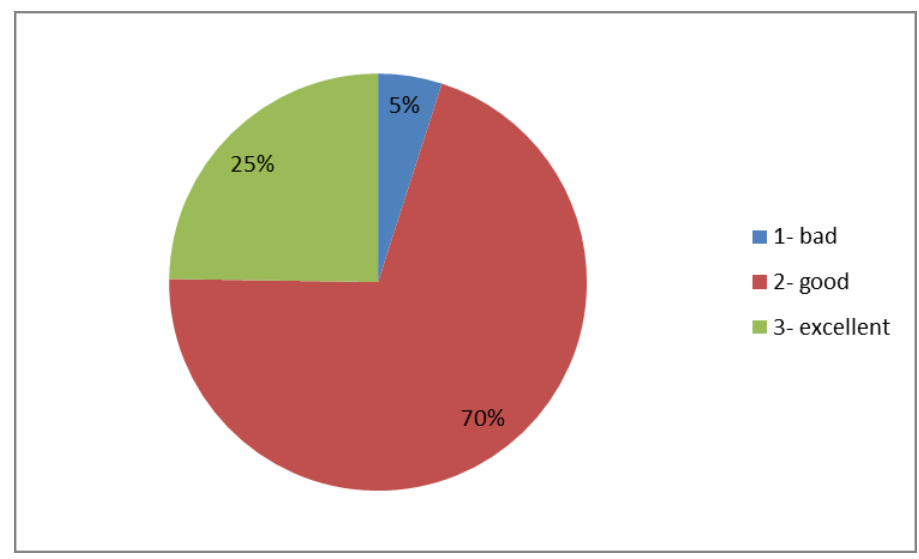

Fig. 7. Evaluation of a tourism staff affability at some hotels and tourism agencies in Sarajevo tourism destination on the Likert scale:

1- bad, 2- good, 3- excellent, according to opinion of tourists, the visistors in 2013-2014 year

(The Survey of Tourists Results, 2013-2014)

The survey of a tourists results shows that the tourism staff affability in Sarajevo destination is mostly good $70 \%$. But, what we want to achieve, is to be an excellent. For now, the share of excellent mark is only $25 \%$. The tourism staff (guide, recepcionist, waiter, cleaner, chambermaid, information consulter, etc.), all of them should be easygoing, available and extremely polite toward guests.

\section{Tab. 4. The total evaluation results of a tourism staff affability in Sarajevo tourism destination on the Likert scale: 1- bad, 2- good, 3- excellent, according to opinion of a tourism managers and tourists}

\begin{tabular}{|c|c|c|}
\hline Manager \& assistant managers & Tourists & Average mark \\
\hline 2,1 & 2,3 & 2,2 \\
\hline
\end{tabular}

(The Survey of Tourism Managers Results, 2013, The Survey of Tourists Results, 2013-2014)

The table above shows the total evaluation results of a tourism staff afability at some hotels and tourism agencies in Sarajevo tourism destination according to the opinion of a tourism managers and tourists who visited Sarajevo during 2013-2014 year. The average mark of tourism staff afability is 2,2 . It's a medium value of a tourism staff affability parameter. Such a mark demonstrates that tourism managers and tourists find it good and accessible. Anyway, the aim is to achive even better results. The tourism staff affability should be rised on the highest level, as it's one of the most important receptional factors of a tourism destination. That's why there should be considered some stimulating factors of affability, such as: a job motivation, job \& a salary satisfaction. For example, there's a high unemployment rate in Sarajevo, the workers could be reminded of that, so they could give their maximum efforts at work. Salary satisfaction for now is $56 \%$, which is not good enough, so it could be rised up at least to achive the demonstrative share of $60 \%$. Satisfaction with is workplace is now $80 \%$, this is actualy the adventage factor that should be used to stimulate the tourism staff affability, "show that you like your job, smile more!" 


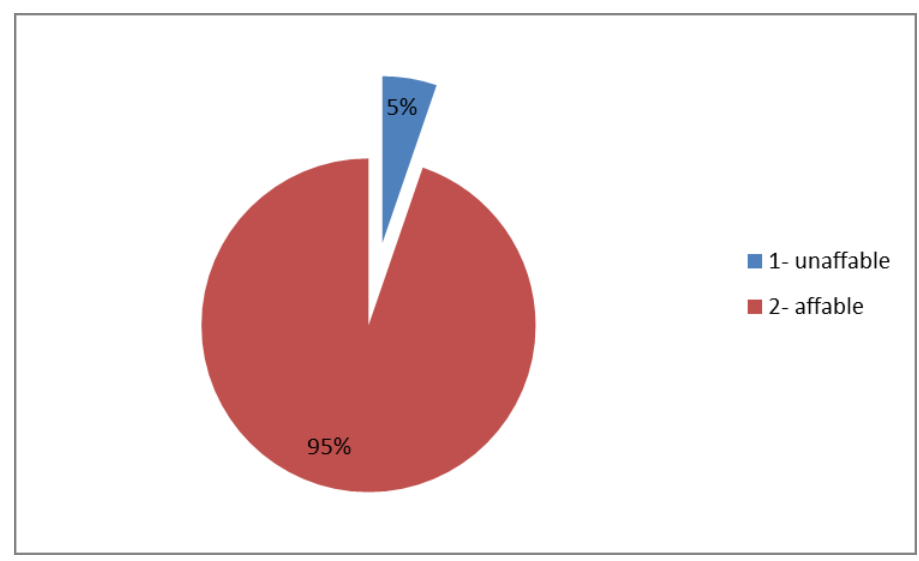

Fig. 8. Evaluation of a locals affability in Sarajevo tourism destination on the nominal scale: 1 - unaffable, 2 - affable, according to opinion of a tourism managers and assistant managers

(The Survey of Tourism Managers Results, 2013)

The evaluation results shows that a locals affability in Sarajevo tourism destination is positive $95 \%$. Tourism managers and assistant managers at some hotels and tourism agencies mostly share opinion that people of Sarajevo are welcoming and easygoing, the locals are mostly willing to help if you ask them.

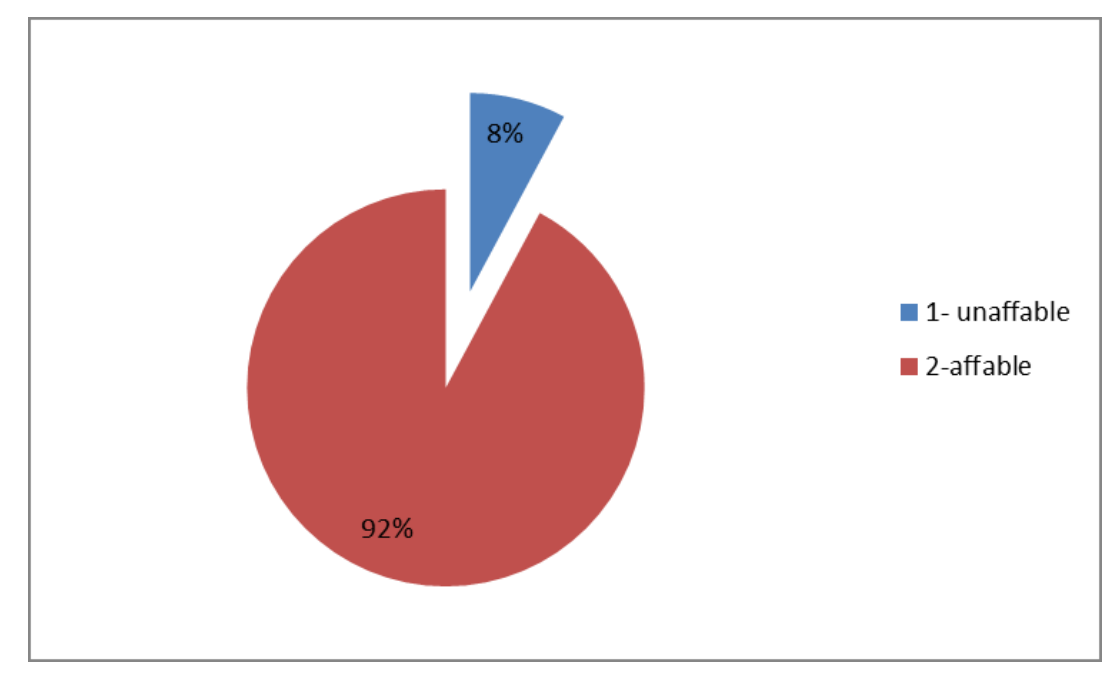

Fig. 9. Evaluation of a locals affability in Sarajevo tourism destination on the nominal scale: 1- unaffable, 2 - affable, according to opinion of a tourists

(The Survey of Tourists Results, 2013-2014) 
According to opinion of a tourists who visited Sarajevo destination during 2013-2014 year, the locals are affable $92 \%$. Same time, most of tourists wished there was other type of scale that they could rate a locals affability in Sarajevo tourism destination with better description. Why? Because "affable means friendly, good-natured, or easy to talk to" (Oxford Dictionary). They explained that their mark of a locals affability in Sarajevo would be closer to a good or medium level of kindness instead of real affability.

Tab. 5. The total evaluation results of a locals affability in Sarajevo tourism destination on the nominal scale: 1- unaffable, 2 - affable, according to opinion of a tourism managers and tourists

\begin{tabular}{|c|c|c|}
\hline Managers & Tourists & Average mark \\
\hline 2 & 1,9 & 1,95 \\
\hline
\end{tabular}

(The Survey of Tourism Managers Results, 2013, The Survey of Tourists Results, 2013-2014)

The table above shows the total evaluation results of a locals afability in Sarajevo tourism destination according to opinion of a tourism managers and tourists who visited Sarajevo during 2013-2014 year. The average mark of locals afability is 1,95. It's a positive, pretty higher value of a locals affability parameter. Such a mark demonstrates that tourism managers and tourists find it pretty well and accessible.

\subsection{English language skills}

The English language skills are necessary for a tourism employees because they are in charge to communicate with tourists from a different parts of the World. "Communication skills, speech and listening are the most important elements of a guest interaction. Speech and the eye contact should express a full devotion to a guest. Carefull listening reflects the respect and true willing to accomplish the guest request. Same time, carefull listening improves to do a job without mistakes. (Tomašević, A., 2009, p. 28, 31). Intercultural communication is a communication process in which people from different cultures try to understand what others from different cultures try to communicate and what their messages mean. (Lustig, M., Koester, J., 1993) In a tourism context, intercultural communication is experienced by tourists when they encounter hosts from a foreign culture, and by hosts when they encounter tourists from a foreign culture. The aim of intercultural communication between tourists and hosts is to understand what each party tries to communicate: hosts want to understand the tourists' needs and deliver a product tourists want, and tourists want to communicate their needs to hosts to receive the product they want. (Reisinger, Y., 2009, p. 167) Language is the method of human communication. Speak the same language means to understand one another as a result of shared opinions or values. (Oxford Dictionary, 2015) 


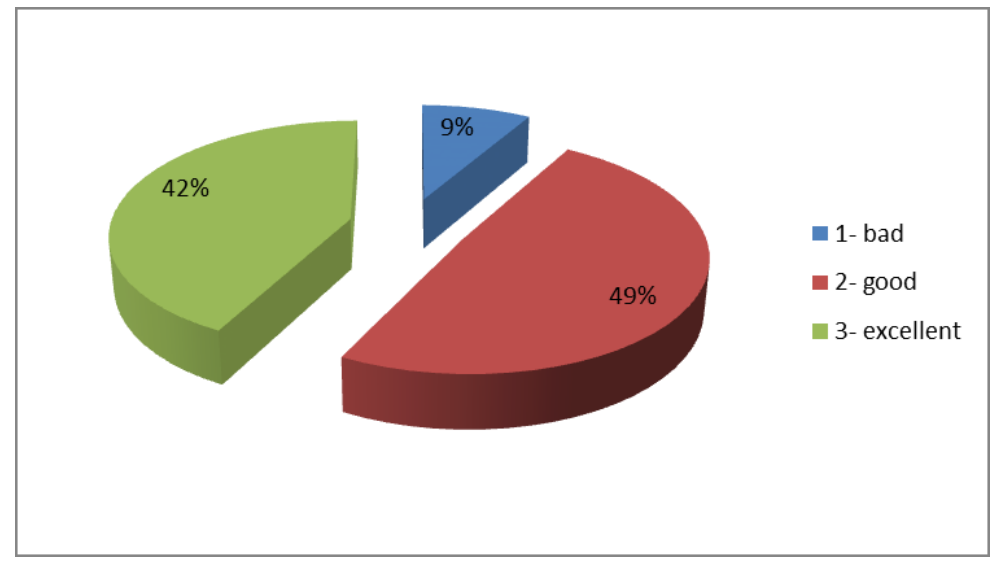

Fig. 10. Evaluation of the English language skills at tourism employees at some hotels and tourism agencies in Sarajevo destination on the Likert scale:

1- bad, 2- good, 3- excellent, according to a personal assessment

(The Survey of Tourism Employees Results, 2013)

The survey results shows that half of a tourism employees at some hotels and agencies in Sarajevo destination have a good English language skills 50\%. It's very important to emphasize that, same time, there's a high percent of employees with an excellent English language skills $42 \%$. Bad English take the smallest share of Sarajevo tourism employees only $9 \%$. However, such a tourism employees, they are good at some other language skills (turkish, arabic, german, etc.).

Tab. 6. The total evaluation results of the English language skills at some tourism employees in Sarajevo tourism destination on the Likert scale:

1- bad, 2- good, 3- excellent

\begin{tabular}{|l|c|c|}
\hline VALUE & MARK & RESPONDENT \\
\hline Low & 1 & 5 \\
\hline Medium & 2 & 29 \\
\hline High & 3 & 25 \\
\hline Average: & 2,3 & 59 \\
\hline
\end{tabular}

(The Survey of Tourism Employees Results, 2013)

The table above shows the total evaluation results of the English language skills at some tourism employees in Sarajevo destination. The average mark of their English skills is 2,3. It's a medium value that demonstrates that tourism employees find their English language skills pretty good. 

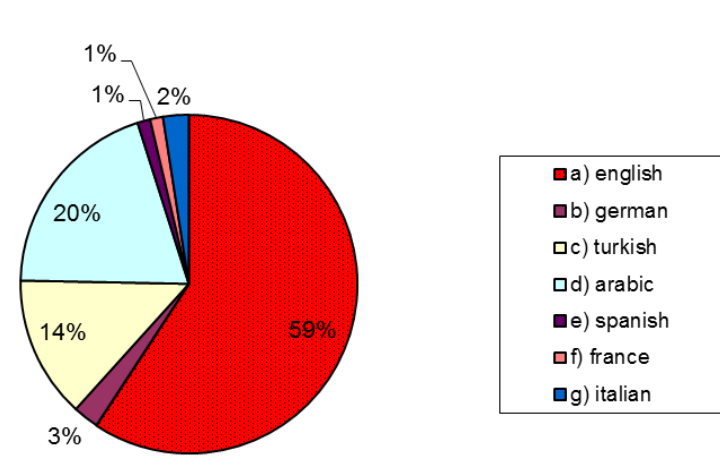

\section{Fig. 11. The most important foreign language at the hospitality $\&$ tourism services sector of Sarajevo tourism destination}

(The Survey of Tourism Employees Results, 2013)

The figure above (fig.11) shows the foreign languages importance at the hospitality \& tourism services sector of Sarajevo tourism destination. English is the most needed language in their job $59 \%$. This is a significant share close to $60 \%$, so it can be evaluated as demonstrative popularity (The Survey Guide, 2001) of English language. Besides, there's a large percentage of employees who considered Arabic and Turkish language as the most important (Arabic 20\%, Turkish 14\%). Such assessment by tourism employees indicates the tourist origin structure of Sarajevo tourism destination. Turks and Arabs are the highest participation tourists of Sarajevo lately. On the survey that was taken in a two year period (2013-2014), 1/3 of total respondents were exactly tourists from Arabic countries $31 \%$. They came mostly from a highly developed countries of Arab World: Qatar, Kuwait, United Arabic Emirates, etc. "The highest participation in a total number of tourist visitors of Sarajevo in 2013 year had Turks (17,3\%), Croats (16,7\%), Slovenians $(7,0 \%)$, Serbians $(4,9 \%)$ and Germans $(3,7 \%)$. Same time the highest participation in a total overnight stays made tourists from Turkey $(16,8 \%)$, Croatia $(14,8 \%)$, Kuwait $(5,8 \%)$, Slovenia (5,7\%) and Serbia (4,6\%)." (Tourism Association of Sarajevo Canton) "The longest-staying visitors of Sarajevo comes from Arabic countries." (Aganović, H., 2014)

\section{Conclusions}

After the survey analysis, based on their evaluation results and discussions, it is necessary to do a ranking of examined parameters according to their values. The rank position demonstrates the parameter importance for a tourism planning and a tourism \& geographical development of Sarajevo tourism destination. 
Tab. 7. Ranking of hospitality parameters according to the measured value

\begin{tabular}{|l|c|c|l|}
\hline PARAMETER / INDICATOR & SCALE & MARK & RANK \\
\hline Qualifications of tourism staff & $1-4$ & 3 & higher \\
\hline Affability of locals & $1-2$ & 1,95 & higher \\
\hline English language skills at tourism staff & $1-3$ & 2,3 & medium \\
\hline Affability of tourism staff & $1-3$ & 2 & medium \\
\hline
\end{tabular}

(The Survey of Tourism Managers, Tourism Employees and Tourists, 2013-2014)

The ranking table shows the evaluation results of a hospitality indicators of Sarajevo tourism destination. Parameters of the higher value are: qualifications of tourism staff and affability of locals. Parameters of medium value are: affability of tourism staff and their English language skills. The fact that there is a good quality of tourism staff and affable locals is very important for tourists who visit a tourism destination. This way they can feel welcoming and respected. Tourists can feel safety as they can ask whatever and they know that there's a good service which can respond to their requests. What is important to achieve is to rise up the tourism staff affability and their English language skills on the highest level. This is because the tourism staff is the basic receptional subject of a tourism destination. Same time, it has a big influence on a destination tourism \& geographical development. Positive impressions and experiences of tourists are very powerfull factor that can stimulate increase in the number of tourists especially foreign visitors. They can even wish to visit Sarajevo again because of extremely polite tourism workers who can understand them well and that way accomplish their needs. Therefore, hospitality can represent a strong foundation for a tourism \& geographical development. It must be given a huge importance of planning and development issues in the tourism and hospitality sector such as a sustainability, tourism \& hospitality jobs, strong tourism potentials such as a very professional tourism staff, very kind locals of a tourism destination, English skills on the top level, etc. This study explore the adventages of Sarajevo hospitality such as a well educated tourism workers, affable people, knowing of English language (tourism staff)... Same time, it shows us some disadvantages at hospitality, such as a huge but not really adequate diversity of a tourism staff professions, or nepotism problems at a hospitality and tourism employment system... Recommended activities should consider implementation of supervisor monitoring at hotels and tourism agencies, the tourism staff evaluation, as well as planning the courses and workshops of a tourism culture \& education. Besides, it is necessary to promote (via media, internet, etc.) tourism educational programmes in Sarajevo tourism destination with the main goal "to raise tourism conscious of locals". Locals mostly understand the importance of tourist visits to their place, they are even kind already, but what is stil missing is the better english skills. In order to improve the english language skills of inhabitants and tourism workers as well, it's necessary to give more attention to the practicing of English conversation at preschools, schools, faculties, work, all levels! There could be provided the free courses of english as well. Future strategy of hospitality \& tourism planning should encourage open competitions for a workplace rather then private recommendations. This way we should provide a system for better employment results "the best one, with the right qualifications, get the job! In conclusion, 
the hospitality generally is recognized as a medium to higher value that practicaly demonstrates more then a good hospitality service of Sarajevo tourism destination.

\section{References:}

1. Aganović, H. (2014): Interview at agency "Patria". Marketing office of Hotels Ilidža Sarajevo, Sarajevo

2. Digital Archive of Institute for Statistics of Federation of Bosnia and Herzegovina, Sarajevo

3. Dobre, R., Rusković, P., Čivljak, M. (2004): "Management of tourism destination". Higher School of Tourism Management, Sibenik

4. Institute for Statistics of Federation of Bosnia and Herzegovina, Sarajevo

5. Jovičić, Ž. (1986): "Tourism geography". Scientific Book, Belgrad

6. Khan, M. (2012): Comparative Overview of the Impact of Hospitality \& Tourism Industry on a Nation's Development- Opportunities \& Constraints with reference to Armenia. USAID EDMC Project International Consultant

7. Lustig, M., \& Koester, J. (1993): "Intercultural competence." Harper Collins College Publishers, New York

8. Prebežac, D. (2012/2013): "Research of Tourism Markets." Ekonomic faculty of University of Zagreb, Zagreb

9. Reisinger, Y. (2009): "International tourism- cultures and behaviour." ButterworthHeinemann, Elsevier, Oxford

10. Smet, T. (2003): "The definition(s) of hospitality and tourism in relation to economic studies." Sector analysis project. In partial fulfilment for the requirement of the degree of master of science in International hospitality manager, prof. Prosser. University center "Cesar Ritz"

11. Statistical Yearbook of Canton Sarajevo for 2013 year (2014). Institute for Statistics of Federation of Bosnia and Herzegovina, Sarajevo

12. Taylor-Powell, E. (2009): "Wording for rating scales." Evaluation Specialist, Program Development and Evaluation, 2008. (c) 2009. University of Wisconsin, USA

13. The Survey Guide (2001): "Approaches to the Analysis of Survey Data". Statistical Services Centre, The University of Reading, UK

14. Tomašević, A. (2009): "Guest care- in the hospitality \& tourism sector." Agency for Vocational Education. British Council Montenegro. Regional project Skills\&Work

15. Tourism Association of Sarajevo Canton: statistical data and informations, Sarajevo

16. Vogt, W. Paul (1999). "Dictionary of statistics and methodology." Sage Journals, Thousand Oaks, California

17. Wilson, B. (2011): "Employment Law Bits: Nepotism in the Workplace- is this illegal?". Bacon/Wilson, Attorneys at Law, Spriengfield, 2005-2014

18. http://bwlaw.blogs.com/employment law bits/2014/09/nepotism-in-the-workplace-is-itdiscrimination.html

19. http://ethics.unwto.org/en/content/global-code-ethics-tourism

20. http://ethics.unwto.org/en/content/global-code-ethics-tourism

21. http://psychology.ucdavis.edu/faculty_sites/sommerb/sommerdemo/scaling/levels.htm

22. http://survey.cvent.com/blog/market-research-design-tips-2/levels-of-measurement-forsurvey-variables-part-i

23. http://www.oxforddictionaries.com/definition/english/evaluate

24. http://www.oxforddictionaries.com/definition/english/evaluation

25. http://www.oxforddictionaries.com/definition/english/hospitality

26. http://www.oxforddictionaries.com/definition/english/identification

27. http://www.oxforddictionaries.com/definition/english/identify

28. http://www.oxforddictionaries.com/definition/english/language

29. http://www.oxforddictionaries.com/definition/english/ranking 
30. http://www.sarajevo.ba/ba/stream.php?kat=424

31. http://www.uwex.edu/ces/4h/evaluation/documents/Wordingforratingscales.pdf

32. https://en.wikipedia.org/wiki/Likert_scale 